\title{
41 劣性遗伀子形式を示す非症侯群性難聴の臨床像一青森県の家系の検討一
}

\author{
阿部聡子，宇佐美真一，新川秀一
}

弘前大学耳鼻咽喉科

一般に常染色体出性遭伝の研究は造伝子のheterogeneity のために原区造伝子の特定が林難であったが，当地方は従来，人 の交流が少なく、迪伝子のhomogeneity が保たれている可能性が融い。昨年の本学会ではミトコンドリア遗伝子変異による難

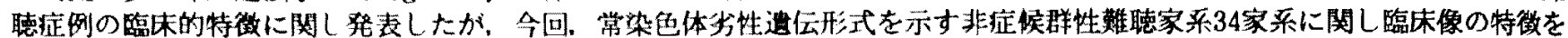
ま之め分類を試みた結果，聴力像から大きく 3 大の多ブに分類されることが明らかとなった。第一のグループ（13家系）は

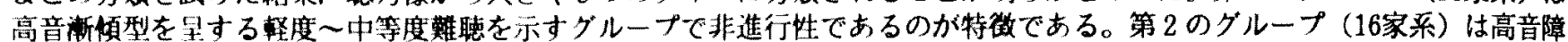

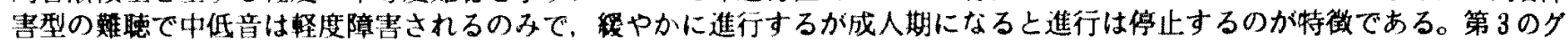

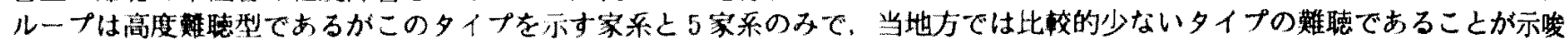
された。現在，連銷解折に上りこれらの家系の原因遗伝子（体）の特定を行っている。

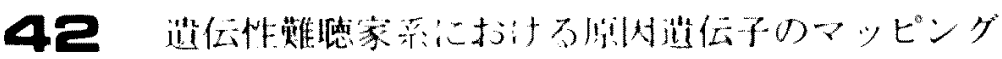

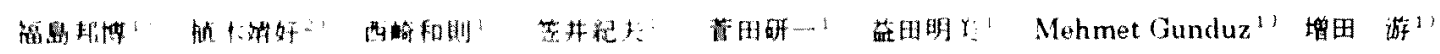

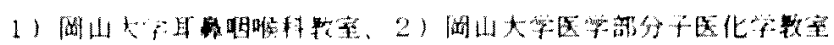

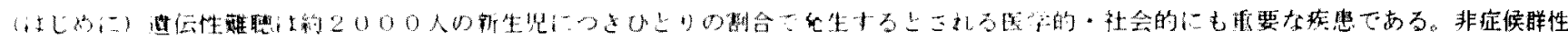

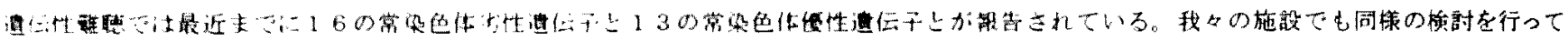

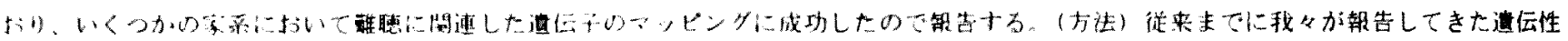

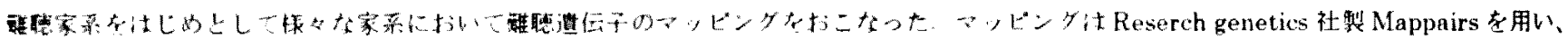

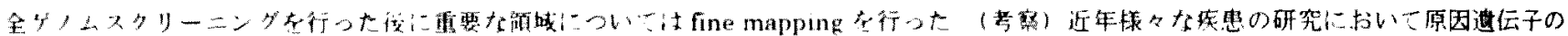

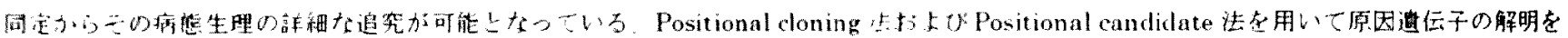

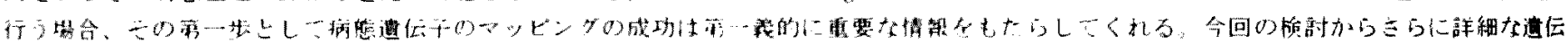

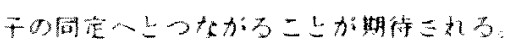

43 突発性難聴の治療経過中の蝸電図、耳音響放射の変化

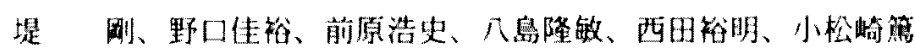

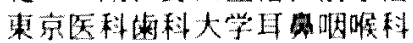

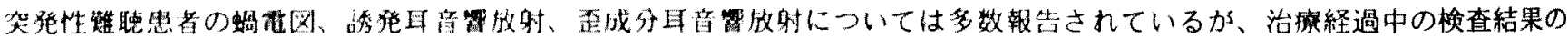
推栘についての惨讨は充分にはなされていないと琹われる。今回我々は、突発性難㯖の診断にて当科でステロイドの点滴治

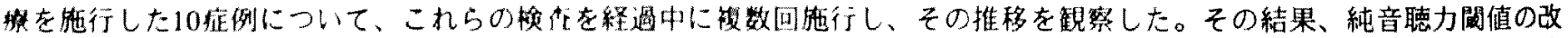

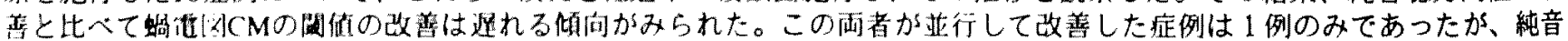

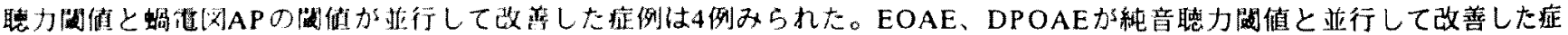

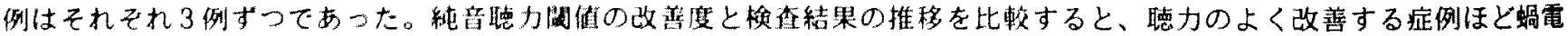

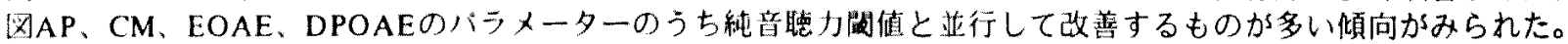

44 音像移動誘発電位の臨床応用一後迷路障害例について一

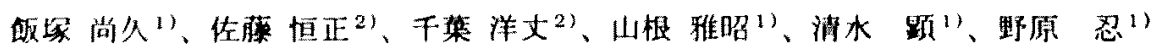

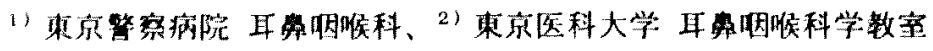

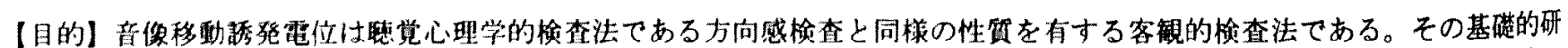

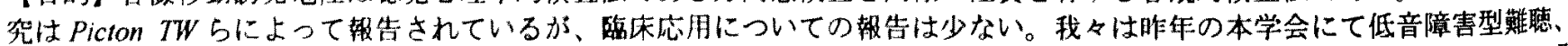

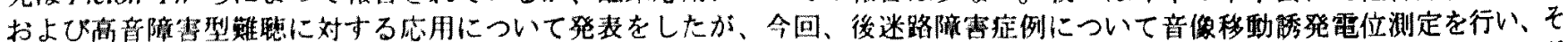

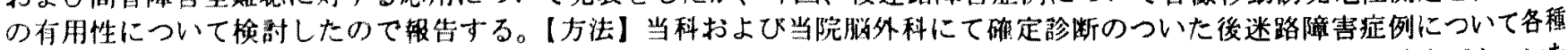

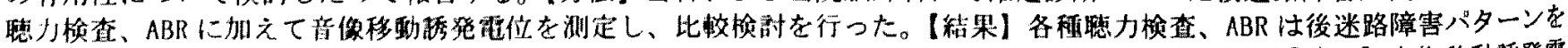

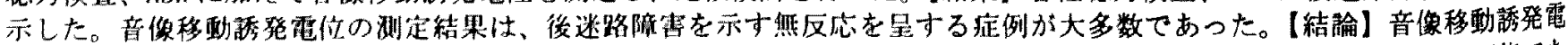

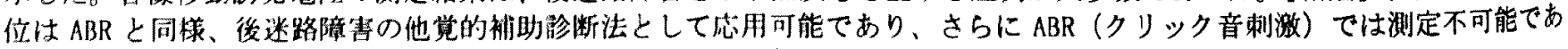

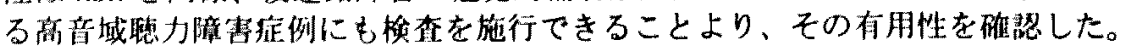

